\title{
Potensi Insektisida Pasak Bumi (Eurycoma longifolia Jack) terhadap Hama Kubis Crocidolomia pavonana (F.) (Lepidoptera: Crambidae)
}

\author{
EKA CHANDRA LINA ${ }^{1)}$, ARNETI ${ }^{1)}$, DJOKO PRIJONO ${ }^{2)}$, DADANG $^{2)}$ \\ ${ }^{1)}$ Jurusan Hama dan Penyakit Tumbuhan, Fakultas Pertanian, Universitas Andalas \\ ${ }^{2)}$ Departemen Proteksi Tanaman, Institut Pertanian Bogor
}

(diterima Oktober 2008, disetujui Januari 2009)

\begin{abstract}
Insecticidal Potency of Pasak Bumi (Eurycoma longifolia Jack) againts Cabbage Pest Crocidolomia pavonana (F.) (Lepidoptera: Crambidae). The research was conducted at Laboratory of Insect Physiology and Toxicology of Plant Protection Department of Bogor Agricultural University from May to July 2008. Leaves, twigs, barks, and roots of Eurycoma longifolia (Pasak bumi) were extracted with hexane, ethyl acetate, and methanol solvens. The extraction was used single method and level method. Insecticidal activity of each extract has been examined in laboratory to major cabbage pests Crocidolomia pavonana using leaf residual method. Methanol root extract from single method and level method caused 100 and $75.5 \%$ mortality of insect test respectively. Hexane and ethyl acetate extracts of leaves, twigs, and barks have low insecticidal activity. The antifeedant effect worked at insect test and varied depends on concentration level. Antifeedant effect also contributed to mortality of larvae along with toxicity of each extract.
\end{abstract}

KEY WORDS: Extract, mortality, bioactivity, Eurycoma longifolia, Crocidolomia pavonana

\section{PENDAHULUAN}

Famili Simaroubaceae dikenal secara luas sebagai tanaman dengan khasiat obat (Padua \& Bunyapraphatsara 1999). Bahan aktif berupa kuasinoid ditemukan di seluruh bagian tanaman dengan konsentrasi berbeda. Kuasinoid memiliki aktivitas biologi dengan spektrum yang luas, beberapa diantaranya telah diuji lanjut dan dipublikasikan. Sifat antitumor dan antikanker sangat nyata, tetapi kebanyakan komponennya sangat toksik untuk digunakan secara medis (Guo et al. 2005). Sifat toksik tersebut dapat dimanfaatkan dalam bentuk lain yakni penggunaannya sebagai sumber insektisida nabati.

Salah satu spesies yang dikenal luas adalah Eurycoma longifolia atau pasak bumi. Penelitian mengenai sifat insektisida pasak bumi belum banyak dilakukan orang. Syahputra et al. (2001) telah menguji ekstrak aseton akar pasak bumi dari hutan Kalimantan. Perlakuan dengan ekstrak 
tersebut pada konsentrasi $0,5 \%$ dengan metode kontak dapat mematikan $83 \%$ kumbang kacang Callosobrachus maculatus. Selain itu Syahputra juga melaporkan bahwa campuran ekstrak:air:aseton:metanol pada konsentrasi $5 \%$ dapat mematikan $100 \%$ ulat kubis Crocidolomia pavonana (Lepidoptera: Crambidae) dengan metode residu pada daun.

Pasak bumi sangat berlimpah di Indonesia khususnya di daerah Sumatera. Pasak bumi merupakan vegetasi hutan yang dapat dijumpai di hutan-hutan Sumatera. Keberadaan yang melimpah dan potensi insektisida yang cukup menjanjikan akan sangat berperan dalam mendukung program pertanian ramah lingkungan dan pertanian berkelanjutan.

Penelitian ini menggunakan serangga uji $C$. pavonana yang merupakan hama penting pada tanaman Brassicaceae seperti kubis, sawi, petsai, lobak, dan brokoli. Daerah persebaran hama ini meliputi Afrika Selatan, Asia Tenggara, Australia, dan Kepulauan Pasifik (Kalshoven 1981).

Tujuan penelitian ini adalah untuk mengetahui aktivitas insektisida nabati dari bagian daun, ranting, kulit batang, dan akar pasak bumi terhadap $C$. pavonana.

\section{BAHAN DAN METODE}

\section{Tempat dan Waktu Penelitian}

Penelitian dilaksanakan di Laboratorium Fisiologi dan Toksikologi Serangga, Departemen Proteksi Tanaman, Fakultas Pertanian, Institut Pertanian Bogor (IPB) dari Mei sampai Juli 2008.

\section{Perbanyakan Tanaman Brokoli}

Pakan serangga uji mengunakan daun brokoli (Brassica oleracea L. var. Merk SAKATA, Green magicBroccoli F1 Hybrid) yang ditanam pada kantung plastik hitam (polybag). Benih brokoli disemai pada nampan semai berisi "media tanam organik". Seiring dengan penyemaian dilakukan pemupukan dengan pupuk majemuk pelepasan perlahan "Dekastar" (NPK 22-8-4). Setelah berumur kurang lebih 4 minggu, bibit brokoli dipindahkan ke polybag (5:1) yang berisi media tanam tanah dan pupuk kandang dengan perbandingan 3:1 sebanyak satu bibit per polybag. Pemeliharaan dilakukan setiap hari, meliputi penyiraman, penyiangan gulma, dan pengendalian hama secara mekanis jika ditemukan hama pada tanaman. Daun brokoli dari tanaman yang berumur $\geq 2$ bulan digunakan sebagai pakan larva $C$. pavonana pada perlakuan dan pemeliharaan.

\section{Pembiakan Serangga Uji}

Pembiakan C. pavonana dilakukan di Laboratorium Fisiologi dan Toksikologi Serangga, Departemen 
Proteksi Tanaman IPB sejak tahun 1987. Pembiakan serangga mengikuti prosedur yang digunakan oleh Prijono dan Hassan (1992). Imago $C$. pavonana dipelihara dalam kurungan plastik-kasa berbingkai kayu (50 cm x $50 \mathrm{~cm} \times 50 \mathrm{~cm}$ ) dan diberi makan larutan madu $10 \%$ yang diresapkan pada segumpal kapas. Sebagai tempat bertelur digunakan daun brokoli yang tangkainya dimasukkan dalam tabung film berisi air. Kelompok telur pada daun brokoli dikumpulkan setiap hari. Menjelang menetas, kelompok telur dipindahkan ke dalam wadah plastik $(28 \mathrm{~cm} \mathrm{x} 20 \mathrm{~cm} \mathrm{x} 5 \mathrm{~cm}$ ) berjendela kasa yang dialasi dengan kertas stensil, lalu di dalamnya diletakkan daun brokoli bebas pestisida sebagai makanan larva. Larva instar II digunakan untuk pengujian. Bila tidak digunakan untuk pengujian, larva dipelihara lebih lanjut dalam wadah plastik (35 cm x $25 \mathrm{~cm} \times 6 \mathrm{~cm}$ ) dengan pakan daun brokoli bebas pestisida. Menjelang berpupa, larva dipindahkan ke dalam wadah plastik lain yang berisi serbuk gergaji sebagai medium berpupa. Pupa yang terbentuk beserta kokonnya diletakkan dalam kurungan kasa plastik seperti di atas hingga imago muncul untuk pemeliharaan selanjutnya.

\section{Tumbuhan Sumber Ekstrak}

Bahan tumbuhan yang digunakan adalah daun, ranting, kulit batang, dan akar pasak bumi yang diperoleh dari
Taman Nasional Siberut (Mentawai), Sumatera Barat.

\section{Ekstraksi}

\section{Ekstraksi Bertingkat}

Daun, ranting, kulit batang, dan akar pasak bumi dipotong-potong $( \pm 3$ $\mathrm{cm})$ kemudian diletakkan diatas nampan bambu yang dialasi kertas koran. Bahan tanaman dibiarkan kering udara tanpa terkena cahaya matahari langsung. Setelah kering, bagian tanaman tersebut, masingmasing digiling dengan menggunakan alat grinder. Bahan tumbuhan yang sudah menjadi serbuk siap untuk digunakan.

Ekstraksi bertingkat dilakukan melalui tiga tahapan ekstraksi dengan tiga jenis pelarut yang makin polar, yaitu heksana, etil asetat, dan metanol. Pada tahap pertama, $50 \mathrm{~g}$ serbuk masing-masing bagian tanaman dimasukkan ke dalam labu erlenmeyer dan direndam dalam $500 \mathrm{ml}$ heksana selama sekurang-kurangnya 24 jam. Kemudian cairan ekstrak disaring menggunakan corong kaca (diameter 9 $\mathrm{cm}$ ) beralaskan kertas saring. Hasil saringan ditampung dalam labu penguap, kemudian diuapkan dengan rotary evaporator pada suhu $45^{\circ} \mathrm{C}$ dan tekanan 337 mbar. Heksana yang diperoleh kembali dari penguapan digunakan untuk merendam ulang ampas ekstrak tersebut. Perendaman ampas masing-masing ekstrak diulang tiga kali. Ekstrak yang diperoleh 
disimpan di dalam lemari es pada suhu $\pm 4^{\circ} \mathrm{C}$ sampai digunakan untuk pengujian.

Pada tahap kedua, ampas dari ekstrak heksana setiap jenis tumbuhan dikeringkan di dalam kamar asap (fume hood), kemudian ampas masing-asing bagian tanaman direndam ulang dalam $500 \mathrm{ml}$ etil asetat. Hasil rendaman disaring dan diuapkan dengan langkahlangkah seperti pada tahap pertama pada tekanan 240 mbar. Pada tahap ketiga, ampas dari ekstrak etil asetat dikeringkan lagi, kemudian ampas masing-masing bagian tanaman direndam ulang dengan $500 \mathrm{ml}$ metanol. Hasil rendaman disaring dan diuapkan dengan langkah-langkah seperti pada tahap sebelumnya pada tekanan 337 mbar. Ekstrak yang diperoleh pada tahap dua dan tiga disimpan di dalam lemari es pada suhu $\pm 4^{\circ} \mathrm{C}$ sampai digunakan untuk pengujian.

\section{Ekstraksi Langsung dengan Metanol}

Serbuk akar pasak bumi sebanyak $50 \mathrm{~g}$, dimasukkan ke dalam labu erlenmeyer dan direndam dengan metanol sebanyak $500 \mathrm{ml}$ selama sekurang-kurangnya 24 jam. Hasil rendaman disaring menggunakan corong kaca (diameter $9 \mathrm{~cm}$ ) beralaskan kertas saring. Hasil saringan ditampung dalam labu penguap, kemudian diuapkan dengan rotary evaporator pada suhu $45^{\circ} \mathrm{C}$ dan tekanan 337 mbar. Metanol yang diperoleh kembali dari penguapan digunakan untuk merendam ulang ampas ekstrak tersebut. Perendaman ampas ekstrak buah pasak bumi diulang berkali-kali hingga pelarut jernih. Ekstrak metanol langsung buah pasak bumi yang diperoleh disimpan di dalam lemari es pada suhu $\pm 4^{\circ} \mathrm{C}$ hingga saat digunakan untuk pengujian.

\section{Uji Toksisitas}

Ekstrak heksana, etil asetat dan metanol bagian tanaman pasak bumi masing-masing diuji pada konsentrasi 0,5 dan 2,5\%. Setiap komponen aktif dicampur dengan pelarut metanol dan perekat Agristik kemudian diencerkan dengan air sesuai konsentrasi yang telah ditentukan. Konsentrasi akhir metanol dan Agristik dalam sediaan uji masing-masing 1 dan $0,2 \%$.

Potongan daun brokoli (4 cm x 4 $\mathrm{cm})$ dicelup satu per satu dalam suspensi ekstrak pada konsentrasi tertentu hingga basah merata, kemudian dikeringudarakan. Daun kontrol dicelup dalam larutan kontrol yang sesuai. Satu potong daun perlakuan dan daun kontrol diletakkan secara terpisah dalam cawan petri (diameter $9 \mathrm{~cm}$ ) beralaskan tisu yang ukurannya melebihi diameter cawan. Cawan petri diletakkan pada posisi terbalik. Alas tisu diletakkan pada bagian tutup cawan dan bagian dasar cawan ditutupkan di atas tisu. Dengan demikian, bagian tutup dan dasar cawan tersekat tisu sehingga larva uji tidak dapat keluar dari dalam cawan. 
Larva $C$. pavonana instar II yang baru ganti kulit, sebanyak 15 ekor, dimasukkan ke dalam setiap cawan petri yang telah berisi daun perlakuan atau daun kontrol, lalu larva tersebut dibiarkan makan selama 24 jam. Pada uji pendahuluan ini, setiap perlakuan dan kontrol diulang tiga kali. Setelah 24 jam ditambahkan daun perlakuan dan daun kontrol seperlunya. Dua puluh empat jam berikutnya, daun perlakuan diganti dengan daun tanpa perlakuan, larva yang mati dihitung dan dibuang dari cawan sedangkan yang hidup dibiarkan dan dipelihara dengan tetap diberi makan daun tanpa perlakuan sampai larva tersebut mencapai instar 4. Jumlah larva yang mati dan lama perkembangan larva yang bertahan hidup dicatat. Data mortalitas larva instar 2 dan instar 3 pada pengujian yang sama disajikan dalam bentuk persen kematian sedangkan data lama perkembangan larva dinyatakan sebagai nilai rata-rata \pm simpangan baku.

\section{HASIL DAN PEMBAHASAN}

Ekstraksi 50 g serbuk daun, ranting, kulit batang, dan akar pasak bumi secara berurutan dengan heksana, etil asetat, dan metanol bertingkat maupun metanol langsung memberikan hasil seperti tampak pada Tabel 1. Pada ekstraksi bertingkat daun menghasilkan ekstrak tertinggi baik pada pelarut heksana, etil asetat, dan metanol, selanjutnya diikuti dengan bagian tanaman ranting, kemudian akar, dan terakhir kulit batang. Estraksi akar pasak bumi dengan metanol langsung memberikan hasil yang tidak jauh berbeda dibandingkan dengan ekstraksi metanol akar pasak bumi secara bertingkat.

Ekstraksi bertingkat dan ekstraksi langsung dengan pelarut metanol memberikan hasil ekstrak terbanyak. Hal ini menunjukkan bahwa senyawasenyawa yang terkandung pada daun, ranting, kulit batang, dan akar pasak bumi banyak yang terlarut dalam pelarut semi polar.

Tabel 1. Hasil ekstraksi bagian tanaman E. longifolia dengan beberapa jenis pelarut

\begin{tabular}{lcccc}
\hline Bagian Tanaman & \multicolumn{4}{c}{ Hasil ektraksi dalam pelarut (gr) } \\
\cline { 2 - 5 } & Heksana & Etil asetat & Metanol & $\begin{array}{c}\text { Metanol } \\
\text { Langsung }\end{array}$ \\
\hline Daun & 0,9779 & 0,5387 & 4,2234 & - \\
Ranting & 0,3097 & 0,6080 & 1,8514 & - \\
Kulit batang & 0,1883 & 0,1383 & 0,7809 & - \\
Akar & 0,1954 & 0,4417 & 1,3210 & 1,0508 \\
\hline
\end{tabular}


Pengujian ekstrak heksana masingmasing bagian tanaman pada konsentrasi 0,1 dan $0,5 \%$ terhadap $C$. pavonana menunjukkan aktivitas yang rendah $(<10 \%)$. Mortalitas tertinggi sebesar $8,88 \%$ tampak pada ekstrak heksana kulit batang pada konsentrasi $0,1 \%$. Lama perkembangan larva yang diberi perlakuan ekstrak heksana dari instar 2 sampai instar 4 umumnya tidak berbeda dengan kontrol, yaitu sekitar 4 hari (Tabel 2).

Estrak etil asetat daun, ranting, kulit batang, dan akar pasak bumi juga memiliki aktivitas yang rendah berkisar antara 2,22 - 31,11\%. Kematian tertinggi tampak pada ekstrak etil asetat akar yang mematikan 31,11\% larva uji, sedangkan ekstrak etil asetat bagian tanaman lainnya tidak menunjukkan aktivitas yang baik.
Efek penghambatan perkembangan ekstrak heksana dan etil asetat bervariasi dengan efek penghambatan tertinggi tampak pada ekstrak etil asetat akar pasak bumi pada konsentrasi $0,5 \%$ yaitu sebesar 2,14 hari lebih lama dibandingkan kontrol (Tabel 3).

Ekstrak metanol bertingkat daun, ranting, dan kulit batang pada konsentrasi $0,1 \%$ dan $0,5 \%$ tidak aktif terhadap larva C. pavonana instar 2 . Aktivitas sedang tampak pada ekstrak metanol bertingkat akar pasak bumi, pada konsentrasi $0,1 \%$ yaitu mematikan 13,33\% larva uji dan pada konsentrasi $0,5 \%$ mematikan 75,55\% larva uji. Ekstraksi dengan metanol langsung dilakukan terhadap ekstrak yang memberikan hasil uji hayati baik yaitu akar pasak bumi (Tabel 4).

Tabel 2. Mortalitas dan perkembangan $C$. pavonana yang diberi perlakuan ekstrak heksana daun, ranting, kulit batang, dan akar E. longifolia

\begin{tabular}{lcccc}
\hline \hline Bagian & Perlakuan & \multicolumn{2}{c}{ Mortalitas (\%) } & $\begin{array}{c}\text { Lama } \\
\text { Tanaman }\end{array}$ \\
\cline { 2 - 4 } & & Instar 2 & Instar 3 & $\begin{array}{c}\text { perkembangan } \\
(\mathrm{X} \pm \mathrm{SD})\end{array}$ \\
\hline Daun & Kontrol & 0 & 0 & $4,11 \pm 0,32$ \\
& $0,1 \%$ & 0 & 0 & $4,05 \pm 0,21$ \\
Ranting & $0,5 \%$ & 0 & 0 & $4,07 \pm 0,26$ \\
& Kontrol & 0 & 0 & $4,24 \pm 0,48$ \\
Kulit batang & $0,1 \%$ & 6,52 & 0 & $4,18 \pm 0,45$ \\
& $0,5 \%$ & 2,22 & 2,22 & $4,21 \pm 0,41$ \\
Akar & Kontrol & 0 & 0 & $4,35 \pm 0,48$ \\
& $0,1 \%$ & 8,88 & 0 & $4,26 \pm 0,59$ \\
& $0,5 \%$ & 4,44 & 2,22 & $4,19 \pm 0,50$ \\
& Kontrol & 2,22 & 0 & $4,00 \pm 0,00$ \\
& $0,1 \%$ & 0 & 0 & $4,09 \pm 0,37$ \\
\hline
\end{tabular}


Tabel 3. Mortalitas dan perkembangan C. pavonana yang diberi perlakuan ekstrak etil asetat daun, ranting, kulit batang, dan akar E. longifolia

\begin{tabular}{|c|c|c|c|c|}
\hline \multirow[t]{2}{*}{ Bagian Tanaman } & \multirow[t]{2}{*}{ Perlakuan } & \multicolumn{2}{|c|}{ Mortalitas (\%) } & \multirow{2}{*}{$\begin{array}{c}\text { Lama } \\
\text { perkembangan } \\
(\mathrm{X} \pm \mathrm{SD})\end{array}$} \\
\hline & & Instar 2 & Instar 3 & \\
\hline \multirow[t]{3}{*}{ Daun } & Kontrol & 0 & 0 & $3,73 \pm 0,44$ \\
\hline & $0,1 \%$ & 0 & 0 & $4,55 \pm 0,50$ \\
\hline & $0,5 \%$ & 15,56 & 0 & $5,26 \pm 0,44$ \\
\hline \multirow[t]{3}{*}{ Ranting } & Kontrol & 0 & 0 & $4,08 \pm 0,29$ \\
\hline & $0,1 \%$ & 2,22 & 0 & $4,73 \pm 0,45$ \\
\hline & $0,5 \%$ & 8,80 & 0 & $4,29 \pm 0,46$ \\
\hline \multirow[t]{3}{*}{ Kulit batang } & Kontrol & 2,22 & 0 & $3,93 \pm 0,33$ \\
\hline & $0,1 \%$ & 0 & 0 & $4,00 \pm 0,00$ \\
\hline & $0,5 \%$ & 0 & 0 & $4,18 \pm 0,39$ \\
\hline \multirow[t]{3}{*}{ Akar } & Kontrol & 0 & 0 & $3,93 \pm 0,25$ \\
\hline & $0,1 \%$ & 2,22 & 0 & $4,56 \pm 0,50$ \\
\hline & $0,5 \%$ & 31,11 & 2,22 & $6,07 \pm 0,64$ \\
\hline
\end{tabular}

Tabel 4. Mortalitas dan perkembangan C. pavonana yang diberi perlakuan ekstrak metanol daun, ranting, kulit batang, dan akar E. longifolia

\begin{tabular}{lcccc}
\hline \hline Bagian Tanaman & Perlakuan & \multicolumn{2}{c}{ Mortalitas (\%) } & $\begin{array}{c}\text { Lama } \\
\text { perkembangan } \\
\text { (X } \pm \text { SD) }\end{array}$ \\
\cline { 3 - 4 } Daun & & Instar 2 & Instar 3 & \\
& Kontrol & 0 & 0 & $4,02 \pm 0,15$ \\
\multirow{2}{*}{ Ranting } & $0,1 \%$ & 0 & 0 & $4,76 \pm 0,48$ \\
& $0,5 \%$ & 6,67 & 0 & $5,97 \pm 0,15$ \\
& Kontrol & 0 & 0 & $4,15 \pm 0,37$ \\
Kulit batang & $0,1 \%$ & 0 & 0 & $4,15 \pm 0,42$ \\
& $0,5 \%$ & 0 & 0 & $4,86 \pm 0,34$ \\
Akar & Kontrol & 0 & 0 & $4,00 \pm 0,00$ \\
& $0,1 \%$ & 0 & 0 & $4,40 \pm 0,49$ \\
& $0,5 \%$ & 2,22 & 0 & $4,98 \pm 0,15$ \\
& Kontrol & 0 & 0 & $4,11 \pm 0,32$ \\
& $0,1 \%$ & 13,33 & 0 & $5,36 \pm 0,54$ \\
& $0,5 \%$ & 75,55 & 0 & $5,64 \pm 0,81$ \\
\hline
\end{tabular}

Hasil yang diperoleh tampak pada Tabel 5 Konsentrasi 0,1 dan $0,5 \%$ berturut-turut menyebabkan kematian larva $C$. pavonana 48,88 dan $100 \%$. Hasil ini lebih tinggi jika dibandingkan dengan kematian larva uji yang diberi perlakuan ekstrak metanol dari metode bertingkat pada konsentrasi yang sama.
Hal ini menunjukan bahwa senyawasenyawa yang bersifat toksik bekerja secara sinergis. Pemisahan secara bertingkat menyebabkan senyawa tersebut terpisah berdasarkan tingkat kepolarannya. 
Tabel 5. Mortalitas dan perkembangan C. pavonana yang diberi perlakuan ekstrak metanol langsung akar E. longifolia

\begin{tabular}{cccc}
\hline \hline Perlakuan & \multicolumn{2}{c}{ Mortalitas (\%) } & Lama perkembangan \\
\cline { 2 - 3 } & Instar 2 & Instar 3 & $(\mathrm{X} \pm \mathrm{SD})$ \\
\cline { 2 - 3 } Kontrol & 0 & 0 & $3,56 \pm 0,50$ \\
$0,1 \%$ & 48,88 & 0 & $4,57 \pm 0,59$ \\
$0,5 \%$ & 100 & 0 & $0,00 \pm 0,00$ \\
\hline
\end{tabular}

Penghambatan perkembangan larva uji yang diberi perlakuan ekstrak metanol bertingkat dan ekstrak metanol langsung akar pasak bumi menunjukkan hasil yang relatif sama pada konsentrasi $0,1 \%$ yaitu \pm 1 hari jika dibandingkan dengan kontrol. Sedangkan efek penghambatan perkembangan pada konsentrasi $0,5 \%$ tidak teramati karena seluruh larva uji mati (Tabel 5).

Kematian larva uji memiliki pola yang sama pada perlakuan ekstrak metanol bertingkat dan ekstrak metanol langsung. Kematian larva banyak terjadi pada instar 2 sedangkan pada instar 3 tidak ada kematian, artinya kematian hanya terjadi pada hari pertama dan kedua saja dimana daun yang dipaparkan adalah daun perlakuan yang mengandung bahan aktif pasak bumi. Setelah hari kedua pada saat pakan diganti dengan daun tanpa perlakuan larva uji dapat pulih dan menyelesaikan siklus hidupnya. Hal ini menunjukkan bahwa ekstrak pasak bumi selain bersifat antifeedant bekerja sebagai racun dibandingkan sebagai penghambat pertumbuhan dan perkembangan. Senyawa aktif yang masuk melalui pencernaan mematikan serangga uji. Akibat adanya efek antifeedant, senyawa yang masuk bersama makanan yang dicerna jumlahnya sedikit sehingga tidak mampu mematikan serangga uji. Efek antifeedant di duga kuat memberi sumbangan terhadap kematian larva. Efek penghambatan perkembangan tampak pada perlakuan ekstrak etil asetat (Tabel 3) dan perlakuan ekstrak metanol langsung maupun bertingkat (Tabel 4 \& 5). Tertundanya perubahan larva uji menjadi instar selanjutnya jika dibandingkan dengan kontrol menunjukkan adanya gangguan terhadap proses fisiologi serangga uji oleh bahan aktif pasak bumi dan atau sebagai dampak dari efek antifeedant ekstrak sehingga serangga tidak mau makan. Bahan aktif pasak bumi termasuk golongan kuasinoid, dengan ciri-ciri berasa pahit (Guo et al. 2005).

Metode ekstraksi menggunakan metanol langsung relatif lebih efisien dibandingkan dengan metode ekstraksi bertingkat, terkait dengan jumlah eks- 
trak yang dihasilkan dan aktivitasnya terhadap C. pavonana.

\section{KESIMPULAN}

Bagian tanaman pasak bumi yang potensial sebagai sumber insektisida nabati adalah bagian akar. Bahan aktif pada akar pasak bumi terbawa oleh pelarut metanol dan efisien dengan metode ekstraksi langsung. Bahan aktif yang terkandung dalam akar pasak bumi memiliki aktivitas insektisida cukup kuat terhadap $C$. pavonana.

Mengingat sumber yang memiliki bahan aktif tertinggi adalah akar, perlu dilakukan studi khusus untuk mengetahui kelayakan sebagai sumber pestisida nabati, selain itu perlu dicari alternatif sumber ekstrak melalui teknologi kultur jaringan.

\section{DAFTAR PUSTAKA}

Guo Z, Vangapandu S, Sindelar RW, Walker LA, Sindelar RD. 2005. Biologically active quassinoids and their chemistry: Potential
Leads for drug design. Current Medicinal Chemistry 12: 173190.

Kalshoven LGE. 1981. The Pests of Crops in Indonesia. Van der Laan PA, penerjemah. Jakarta: Ichtiar Baru-van Hoeve.

Padua LS, Bunyapraphatsara N. 1999. Plant Resources of SouthEast Asia (Medicinal and Poisonous Plants 1): Simaroubaceae. Lemmens RHMJ, editor. Netherlands: Buckhuys publishers. hlm 272275.

Prijono D, Hassan E. 1992. Life cycle and demography of Crocidolomia binotalis Zeller (Lepidoptera: Pyralidae) on brocolli in the laboratory. Indon J Trop Agric 4: 18-24.

Syahputra E, Rianto F, Prijono D. 2001. Aktivitas insektisida ekstrak tumbuhan asal Kalimantan Barat terhadap kumbang kacang Callosobruchus maculatus (F.) dan ulat kubis Crocidolomia binotalis ZELLER. Jurnal Ilmu Pertanian Indonesia 10:8-13. 